\title{
Evaluation of bioactive secondary metabolites from endophytic fungus Pestalotiopsis neglecta BAB-5510 isolated from leaves of Cupressus torulosa D.Don
}

\author{
Deeksha Sharma $^{1} \cdot$ Avijit Pramanik $^{2} \cdot$ Pavan Kumar Agrawal $^{1}$
}

Received: 26 May 2016/ Accepted: 9 September 2016/Published online: 29 September 2016

(C) The Author(s) 2016. This article is published with open access at Springerlink.com

\begin{abstract}
Six endophytic fungi were isolated from $\mathrm{Cu}$ pressus torulosa D.Don and identified phenotypically and genotypically. The fungal cultures were further grown and the culture was extracted by two organic solvents methanol and ethyl acetate. The screening was carried out using the agar well diffusion method against human pathogen such as Escherichia coli, Salmonella typhimurium, Bacillus subtilis and Staphylococcus aureus. Isolated strain of Pestalotiopsis sp. was showing prominent antibacterial activity. The crude methanol and ethyl acetate extract of Pestalotiopsis sp. showed MIC of $6.25 \mathrm{mg} / \mathrm{mL}$ for $S$. typhimurium and $S$. aureus which showed its efficacy as a potent antimicrobial. The phytochemical screening revealed the existence of a diverse group of secondary metabolites in the crude extracts of the endophytic fungi that resembled those in the host plant extracts. On the basis of phenotypic characteristics and rDNA sequencing of the ITS region of the endophyte was identified as $P$. neglecta which turned out to be a promising source of bioactive compounds. There is little known about endophytes from C. torulosa D.Don. In this paper we studied in detail the identification of isolated endophytic fungi $P$. neglecta from C. torulosa D.Don and characterization of its active metabolite compounds. The partially purified second fraction (PPF) extracted from the fungal culture supernatant was subjected to gas chromatography followed by mass spectrometry which revealed the presence of many
\end{abstract}

Pavan Kumar Agrawal

p_k_agarwal@rediffmail.com

1 Department of Biotechnology, G. B. Pant Engineering College, Ghurdauri, Pauri, Uttarakhand, 246194, India

2 Department of Microbiology, Central University of Haryana, Mahendergarh, Haryana 123031, India phytochemicals. These results indicate that endophytic fungi $P$. neglecta isolated from medicinal plants could be a potential source for bioactive compounds and may find potential use in pharmaceutical industry.

Keywords Pestalotiopsis neglecta A Antibacterial activity · Cytotoxic assay - GC-MS analysis · Bioactive metabolites

\section{Introduction}

An increase in the number of people in the world having health problems caused by various cancers, drug-resistant bacteria, parasitic protozoans, and fungi is a cause for alarm (Strobel 2003). Development of multiple drug-resistant microbes raised the need to search for new and novel antimicrobials for treatment of human diseases (Wise 2008). An intensive search for newer and more effective agents to deal with these disease problems is now under way and endophytes are a novel source of potentially useful medicinal compounds. Much of microbial diversity of nature remains to be explored, particularly marine microbial environments (Newman et al. 2003). Microorganisms have the ability to utilize various substrates as a consequence of the diversity of their biological and biochemical evolution (Fernandes et al. 2009). The solid substrates they use include, among others, live plants. Both bacteria and fungi are known to cooperate with many plants to form mutually beneficial associations. Actinomycetes and fungi, of all microorganisms studied, have been found to be the most prolific producers of secondary metabolites (Guanatilaka 2006).

There are enormous scopes exist for the recovery of novel fungal species, genera and biotypes from this ecological niche. To some estimate approximately 1.5 million 
fungal species exist in the world (Hawksworth 1991; Hawksworth 2001) while only 100,000 have been discovered and there may be at least one million species of endophytic fungi alone (Dreyfuss and Chapela 1994). In the last few years, considerable knowledge has been accumulated on the biology of endophytic microorganisms (Firakova et al. 2007). Endophytes comprise a large but little explored share of fungal diversity (Yuanab et al. 2011; Perottoab et al. 2013).

A range of microbial species are known to be endophytic, colonizing inter and intracellular spaces of tissues of higher plants without causing apparent damage on the plants in which they live. Often they have proven to be rich sources of bioactive natural products ( $\mathrm{Li}$ et al. 2008; Molina et al. 2012). Mutualistic interactions between endophytes and host plants may result in fitness benefits for both partners (Kogel et al. 2006). The endophytes may provide protection and survival conditions to their host plant by producing a plethora of substances which, once isolated and characterized, may also have potential for use in industry, agriculture, and medicine (Porras-Alfaro and Bayman 2011).

Almost all the plant species $(300,000)$ growing in unexplored area on the earth are host to one or more endophytic organisms (Strobel and Daisy 2003). To date, only a few plants are investigated for their endophytic biodiversity and their potential to produce bioactive secondary metabolites. Studies have been conducted at different parts of the world about the endophytic biodiversity, taxonomy, reproduction, host ecology and their effect on host (Bandra et al. 2001). Currently, endophytes are viewed as outstanding sources of bioactive natural products, because many of them are occupying literally millions of unique biological niches growing in so many unusual environments.

Endophytic fungi are of biotechnological interest due to their potential as a source of secondary metabolites that has been proven useful for novel drug discovery (Yan et al. 2011). Antifungal and antibacterial activities of plant endophytic fungi have been reported by several groups (Liang et al. 2012; Gherbawy and Gashgari 2014; Idris et al. 2013; Bhardwaj et al. 2015). Endophytic fungi has been shown to produce several pharmacologically important compounds such as antimycotics steroid 22-triene-3 $\beta$-ol (Metwaly et al. 2014), anticancer cajanol (Zhao et al. 2013), podophyllotoxin and kaempferol (Huang et al. 2014), anti-inflammatory ergoflavin (Deshmukh et al. 2009), antioxidant lectin (Sadananda et al. 2014), insecticidal heptelidic acid (Zhang et al. 2014), immunosuppressive sydoxanthone A, B (Song et al. 2013) and cytotoxic radicicol (Turbyville et al. 2006).

Metabolites produced by endophytes are being recognized as a versatile arsenal of antimicrobial agents. Some endophytes have been known to possess superior biosynthetic capabilities, owing to their presumable gene recombination with the host, while residing and reproducing inside the healthy plant tissues ( $\mathrm{Li}$ et al. 2005). A high proportion of endophytic fungi $(80 \%)$ produce biologically active compounds in tests for antibacterial, fungicidal and herbicidal activities (Schulz et al. 2002). The continued development of new antimicrobial compounds is important to overcome the difficulties related to the treatment of infections caused by resistant pathogens in accordance with Petersen et al. (2004). Thus, it can be said that endophytic fungi have emerged as an alternative source for the production of new antimicrobial agents.

Plants used in traditional medicine have played a very important role in the search for new bioactive strains of endophytic fungi, as it is possible that their beneficial characteristics are a result of the metabolites produced by their endophytic community (Kaul et al. 2012; Kusari et al. 2013). As higher plants are known to harbor endophytic fungi (Bhardwaj et al. 2015) that are believed to be associated with the production of pharmaceutically important products, in this context, the aims of this work were to characterize the fungal endophyte Pestalotiopsis sp. BAB-5510 associated with Cupressus torulosa D.Don from Pauri, Garhwal region of Uttarakhand and to detect cytotoxic and antimicrobial activities of these fungi against some pathogenic microbes.

Despite this potential, a repertoire of medicinal plants remains to be studied regarding their endophytic composition, for example C. torulosa D.Don. This is a wellknown medicinal plant whose leaves have been proven to have anti-inflammatory, anticonvulsant, antimicrobial, and wound-healing properties (Leite et al. 2004, 2006; Carli et al. 2010; Luiz-Ferreira et al. 2011; Almeida et al. 2013; Chen et al. 2013; Bezerra dos Santos et al. 2015). Due to the medicinal properties of $C$. torulosa, this species was the focus in the present study for a search of endophytic fungi that is able to produce bioactive substances with antimicrobial activity and cytotoxic activity.

Due to the importance of secondary metabolite production by endophytic fungi, the study of these $C$. torulosa associated fungi provides greater understanding of its diversity. This study is the first report about the antimicrobial and cytotoxic activity of endophytic fungi residing in $C$. torulosa leaves in which the fungus Pestalotiopsis neglecta demonstrated the ability to produce bioactive agents with pharmaceutical potential, and may provide a new lead in the pursuit of new biological source of drug candidates.

\section{Materials and methods}

\section{Sample collection and isolation of endophytic fungi}

The sampling scheme was designed with the intention of isolating endophytic fungi from mature and healthy needle 
of C. torulosa D.Don (family: Cupressaceae) from Pauri, Garhwal region. The plant samples were tightly sealed in polythene bags under humid conditions and kept at room temperature. The voucher specimen was deposited at Botanical Survey of India, Dehradun with accession number 115744. The isolation of the fungal endophytes commenced within $24 \mathrm{~h}$ of collection of plant samples.

Needles were cut into $5 \mathrm{~mm}$ long segments. Surface sterilization was done by following the method described by Arnold et al. (2007) with minor modification. Needle segments were surface sterilized by consecutive immersion for $1 \mathrm{~min}$ in $75 \%$ Ethanol then for $1 \mathrm{~min}$ in $0.1 \%$ mercuric chloride. Surface sterilization was followed by several washing steps in autoclaved distilled water (Bisht et al. 2016). The time of the dilution and immersion in ethanol and Mercuric chloride varies with tissues and host (at least three washing require). Under sterile conditions, tissue segments were allowed to surface-dry before plating (Petrini et al. 1982). Five needles segments were then evenly placed in PDA plates augmented with $50 \mu \mathrm{g} / \mathrm{mL}$ of chloramphenicol to avoid bacterial contamination. Plates were sealed with parafilm and incubated at $27 \pm 2{ }^{\circ} \mathrm{C}$ for 5-8 days in BOD incubator. Hyphal tips of the developing fungal colonies were transferred aseptically to fresh PDA plates to get pure cultures of the growing fungi.

\section{Phenotypic and genotypic identification of the endophytic fungi}

The isolated endophytic fungi were initially identified through microscopic examination of colony morphology and reproductive characteristics using slide cultures (Bhardwaj et al. 2014). Primary confirmation of morphological identification of the endophytic fungi was carried out at Forest Research Institute (FRI), Dehradun, India. For genotypic identification, total genomic DNA of the endophytic fungi were isolated directly from actively growing mycelium growing in potato dextrose broth (PDB), using DNA extraction kit (Genei). Fungal DNA was extracted in the laboratory using the protocol of Kariyawasam et al. (2012). The extracted DNA was subjected to the polymerase chain reaction (PCR) using primers ITS1: TCCGT AGGTGAACCTGCGG and ITS4: TCCTCCGCTTGA TATGC for amplification of ITS region (White et al. 1990). Amplified DNA was subjected to DNA sequencing and this DNA sequence was compared with already existing DNA sequences in NCBI GenBank (http://www. ncbi.nlm.nih.gov.blast) to identify the respective fungi. PCR and DNA sequencing was done by the Gujarat State Biotechnology Mission, India. The acquired gene sequence was submitted to the NCBI Gen Bank database and an accession number was obtained.

\section{Secondary metabolite extraction}

The fungi were cultivated on PDB by inoculating selected endophyte cultures in $250 \mathrm{~mL}$ Erlenmeyer flask containing $100 \mathrm{~mL}$ of the medium. The flask was incubated at $28^{\circ} \mathrm{C}$ for 2 week with periodical shaking at $150 \mathrm{rpm}$. After the incubation period, the fermentation broth of the fungus was homogenized by adding $10 \%$ methanol to it. Metabolite was extracted by solvent extraction procedure using ethyl acetate and methanol as organic solvents. To the filtrate equal volume of solvents were added, mixed well for $10 \mathrm{~min}$ and kept for $5 \mathrm{~min}$ till the two clear immiscible layers formed. The upper layer of solvent containing the extracted compounds was separated using separating funnel. Solvent was evaporated and the resultant compound was dried in rotator vacuum evaporator to yield the crude metabolite (Bhardwaj et al. 2015). The crude extract was then dissolved in Dimethyl sulphoxide at $1 \mathrm{mg} / \mathrm{mL}$ of concentration and kept at $4{ }^{\circ} \mathrm{C}$.

\section{Determination of antibacterial activity of fungal crude extracts}

Antibacterial activity of secondary metabolites extracted from $P$. neglecta was screened against Gram-positive and Gram-negative bacterial pathogen such as B. subtilis, $S$. aureus, E. coli and S. typhimurium using agar well diffusion method. Bacterial pathogens were spread on Muller Hinton agar (MHA) plates. Then wells were bore on the agar plates and three concentration of crude extract were poured in separate wells $200,150,100 \mu \mathrm{L}$. Antibacterial activities were detected after an incubation of $24-48 \mathrm{~h}$ at $37{ }^{\circ} \mathrm{C}$. The presence of zone of clearance on plates was used as an indicator of bioactive nature of the strain. As positive control, streptomycin was used and DMSO was used as negative control. Three replicates were carried out for each antibacterial activity test.

\section{Determination of minimum inhibitory concentration}

MIC was determined after antibacterial activity of the fungal crude extracts by the standard method described by Wariso and Ebong (1996) with minor modification. Muller Hinton Broth (MHB) was made and sterilized using autoclave. One milliliter of the prepared broth was dispensed into the test tubes labeled from 1 to 5 using sterile syringe and needle. A stock of MHB containing $25 \mathrm{mg} / \mathrm{mL}$ of the crude extract was prepared. The sterile MHB with $25 \mathrm{mg} /$ $\mathrm{mL}$ crude extract was diluted twofold for five times in sterile tubes aseptically. Then, each tube was inoculated with equal volume of overnight grown bacterial culture. Tube 6 was used as a control for sterility of the medium and tube 7 for viability of the organisms. The final

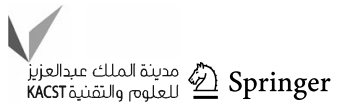


concentration of the extract in each of the test tubes numbered after dilution $25,12.5,6.25,3.125,1.563 \mathrm{mg} /$ $\mathrm{mL}$ were incubated at $37{ }^{\circ} \mathrm{C}$ for $24 \mathrm{~h}$ and examined for growth. The lowest dilution test tube in which growth failed to occur was the MIC of the culture.

\section{Phytochemical screening of fungal crude extracts}

Preliminary phytochemical analysis of the crude extracts of fungi was carried out for the presence of the following metabolites: alkaloids, flavonoids, tannins, phenols, saponins, terpenoids and carbohydrates using standard methods with modification (Devi et al. 2012; Bhardwaj et al. 2015).

\section{MTT cytotoxic assay}

This method is based on the ability of live but not dead cells to reduce a tetrazolium dye to a purple formazan product. In brief, approximately $5 \times 10^{3}$ cells/well of HEK cell line which is a tetraploid non-malignantly transformed human embryonic kidney cell line were seeded into 96 well plates, $100 \mu \mathrm{L}$ of High Glucose Dulbecco's medium (HGD) was added and incubated for $24 \mathrm{~h}$ as to attain $\log$ phase of the cells. After $24 \mathrm{~h}$, different concentrations of fungal crude extract $10,1.0,0.1$ and $0.01 \mu \mathrm{g} / \mathrm{mL}$ were added into the plates and are incubated for two time points 24 and $48 \mathrm{~h}$. After respective incubation period $20 \mu \mathrm{L}$ of MTT $(5 \mathrm{mg} / \mathrm{mL})$ was added and incubated for $2 \mathrm{~h}$ at $37{ }^{\circ} \mathrm{C}$ in a $\mathrm{CO}_{2}$ incubator. After incubation medium was discarded and $200 \mu \mathrm{L}$ of DMSO was added to dissolve the formazan crystals. Then absorbance was read in a spectrophotometer at $560 \mathrm{~nm}$ and cell survival was calculated by the following formula:

Viability $\%=$ Test OD/Control OD $\times 100$

\section{Characterization of bioactive compounds}

\section{Chromatographic detection and partial purification of bioactive metabolite}

Thin layer chromatography (TLC) was performed on methanolic crude extracted from the culture broth of the endophyte with minor modification of Verma et al. (2014). For this, the crude fraction was spotted $(50 \mu \mathrm{L})$ on the TLC plate and chromatography was performed by employing solvent system dichloromethane: methanol $(90: 10 \mathrm{v} / \mathrm{v})$. Spots were visualized by spraying with ceric sulfate; silica residue was extracted and centrifuged and the supernatant was transferred to a microcentrifuge tube. The silica-free supernatant was checked for antibacterial activity. Preparative TLC was carried out to obtain the partial purified sample which showed antibacterial activity.
Detection of bioactive compounds by GC-MS analysis

The compounds separated by TLC were identified using gas chromatograph. The purified methanolic crude extract was subjected to GC-MS analysis to identify the bioactive compounds. The GC-MS-MS analysis of the crude extracts was carried out in a Shimadzu GC-MS-QP 2010 Plus fitted with a RTX-5 $(60 \mathrm{~m} \times 0.25 \mathrm{~mm} \times 0.25 \mu \mathrm{m})$ capillary column in JNU, New Delhi. The instrument was set to an initial temperature of $70{ }^{\circ} \mathrm{C}$, and maintained at this temperature for $2 \mathrm{~min}$. At the end of this period the oven temperature was rose up to $280^{\circ} \mathrm{C}$, at the rate of an increase of $5^{\circ} \mathrm{C} / \mathrm{min}$, and maintained for $9 \mathrm{~min}$. Injection port temperature was ensured as $260^{\circ} \mathrm{C}$ and Helium flow rate as $1 \mathrm{~mL} / \mathrm{min}$. The ionization voltage was $70 \mathrm{eV}$. The samples were injected in split mode as 10:1. Mass spectral scan range was set at $45-450(\mathrm{~m} / \mathrm{z})$. The identification of bioactive compounds present in the extracts was performed by comparing the mass spectra with data from NIST05 (National Institute of Standards and Technology, US), WILEY 8, and FFNSC1.3 (Flavour and Fragrance Natural and Synthetic Compounds) libraries. The name, molecular weight and structure of the components of the test material were ascertained.

\section{Results and discussion}

\section{Isolation and identification of the endophytic fungal strain}

In this study, fungal endophytes associated with coniferous plant $C$. torulosa D.Don, was studied to evaluate the production of bioactive compounds. The plant was taxonomically identified and authenticated by Botanical Survey of India, Dehradun, Uttarakhand. The voucher specimen was deposited there with register number 115744. A total of six different endophytic fungi associated with leaves of $C$. torulosa D.Don were isolated, and morphotypically and genotypically identified as Alternaria alternata, Daldinia sp., Penicillium oxalicum and Pestalotiopsis sp. (Tables 1, 2). The majority of the recovered taxa belong to the Ascomycota. This result supports the Bhardwaj et al. (2015) finding that fungal endophytes from coniferous plant Pinus roxbrghii mainly belong to the ascomycetes. Fungal endophytes are especially common among the Ascomycota, representing at least five classes, dozens of families and large numbers of previously so far unknown species (Clay 1989; Gehlot et al. 2008). Most endophytes of conifer leaves are filamentous Ascomycota (Petrini 1986).

Endophytes have been intensively studied in several unexplored environments around the world (Dar et al. 
Table 1 Morphotypic characterization of endophytic fungi isolated from leaves of from Cupressus torulosa D. Don

\begin{tabular}{|c|c|c|c|c|}
\hline $\begin{array}{l}\text { S. } \\
\text { no. }\end{array}$ & $\begin{array}{l}\text { Code of } \\
\text { isolate }\end{array}$ & Colony characteristics on PDA media & Slide culture & $\begin{array}{l}\text { Probable } \\
\text { endophytic } \\
\text { fungus }\end{array}$ \\
\hline 1 & PCTS13 & Appears olivaceous brown in color & Brush-like conidiophore & $\begin{array}{l}\text { Penicillium } \\
\text { sp. }\end{array}$ \\
\hline 2 & PCTS21 & Appears grayish green in color & $\begin{array}{l}\text { Conidiophores arose singly or in small groups, often branched, straight } \\
\text { and flexuous }\end{array}$ & $\begin{array}{l}\text { Alternaria } \\
\text { alternata }\end{array}$ \\
\hline 3 & PCTS25 & $\begin{array}{l}\text { Appears olive green in color but } \\
\text { appearance of white mycelium after } \\
10 \text { days }\end{array}$ & $\begin{array}{l}\text { The conidiophore branches at the tip. At the end of each branchlet is a } \\
\text { cluster of spore-producing cells called phialides. A chain of spores is } \\
\text { formed from the tip of each phialide }\end{array}$ & $\begin{array}{l}\text { Penicillium } \\
\text { sp. }\end{array}$ \\
\hline 4 & KCTS14 & Appears whitish gray in color & $\begin{array}{l}\text { Conidiophores (annellides) produced within compact fruiting structures } \\
\text { (acervuli or pycnidia). Spores (conidia) 4- to 5-celled, with the two or } \\
\text { three central cells dark brown, and with two or more apical } \\
\text { appendages or hairs; collecting in a wet mass outside the acervulus }\end{array}$ & $\begin{array}{l}\text { Pestalotiopsis } \\
\text { sp. }\end{array}$ \\
\hline 5 & KCTS15 & Appears gray in color & $\begin{array}{l}\text { Conidiophores arose singly or in small groups, often branched, straight } \\
\text { and flexuous }\end{array}$ & $\begin{array}{l}\text { Alternaria } \\
\text { alternata }\end{array}$ \\
\hline 6 & KCTS34 & Appears cottony white in color & $\begin{array}{l}\text { Characterized by the presence of stolons and pigmented rhizoids, multi- } \\
\text { spores, generally globose sporangia }\end{array}$ & Unidentified \\
\hline
\end{tabular}

Table 2 Isolated and identified endophytes from Cupressus torulosa, in relationship with the genus or species, and identity percentage found in the NCBI (National Center for Biotechnology Information) website

\begin{tabular}{llllrr}
\hline Sr. no. & Isolate code & BAB ID & Closely related Fungal sequence & $\%$ identity & Accession no. \\
\hline 1 & PCTS13 & BAB 5444 & Penicillium oxalicum & 99 & KT355727 \\
2 & PCTS21 & BAB 5446 & Alternaria alternata & 100 & KT355729 \\
3 & PCTS25 & BAB 5447 & Penicillium oxalicum & 99 & KT355730 \\
4 & KCTS14 & BAB 5510 & Pestalotiopsis neglecta & 99 & KT355732 \\
5 & KCTS15 & BAB 5445 & Alternaria alternata & 100 & KT355728 \\
6 & KCTS34 & BAB 5448 & Daldinia sp. & 99 & KT355731 \\
\hline
\end{tabular}

2015). Endophytes were distributed in each and every plant species and were investigated for endophytic microbial components (Carroll 2004). Endophytes are chemical synthesizers inside plant. A little work in this line has been done from Garhwal, Himalayan region so for to harness the potential of hidden treasure of endophytes from indigenous plants.

Kumaran et al. (2008a) reported occurrence of Phyllosticta spinarum an endophyte fungus from the needles of Cupressus sp. which was studied as an excellent candidate for taxol production while others have earlier reported various Pestalotiopsis sp. from needle of Cupressus sp. (Maharachchikumbura et al. 2011) and from the leaves of Pinus canariensis (Bagyalakshmi et al. 2012) as a source of various bioactive compounds. Bisht et al. (2016) isolated and identified endophytic fungi from conifer forest plants, C. torulosa D.Don, which were studied with respect to production of bioactive compounds against human pathogenic bacteria. The results revealed that endophytic filamentous fungi isolates belong to the Ascomycetes group, including four different genera: Aspergillus, Cladosporium, Alternaria and Curvularia. The current study showed that C. torulosa is a good source of endophytic fungi, since only one type of culture medium was used for the isolation process, and this unique method allowed the isolation of a considerable number of endophytes. As no microorganism had appeared from the last washing water, so the surface disinfection method was considered efficient.

\section{Production and extraction of secondary metabolites}

The isolates were used for the production and extraction of secondary metabolites. This isolates were extracted with two solvents, i.e., ethyl acetate and methanol.

\section{Antibacterial activity of crude extract by agar well diffusion method}

Fungal crude extract showed promising result by exhibiting maximum antibacterial activity against human bacterial 
Table 3 Antibacterial activity of fungal crude extract

\begin{tabular}{lll}
\hline Inhibition diameter zone $(\mathrm{mm})$ & \\
\hline $\begin{array}{l}\text { Bacterial } \\
\text { pathogens }\end{array}$ & $\begin{array}{l}\text { Methanol crude } \\
\text { extract }\end{array}$ & $\begin{array}{l}\text { Ethyl acetate crude } \\
\text { extract }\end{array}$ \\
\hline$S a$ & 14.5 & 12.0 \\
$E c$ & 14.0 & 15.0 \\
$S t$ & 11.0 & 12.5 \\
$B s$ & 13.0 & 10.0 \\
\hline
\end{tabular}

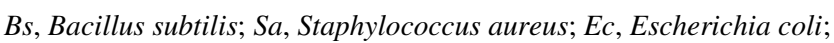
St, Salmonella typhimurium

pathogen. The screening $25 \mathrm{mg} / \mathrm{mL}$ of ethyl acetate and methanol extracts of the fungal culture was conducted using the agar diffusion method against Gram-positive and Gram-negative bacteria. All of the crude extracts of fungi isolates inhibited at least one of the microorganisms studied (data not shown). Among the tested extracts, $P$. neglecta extract inhibited the growth of the all four human pathogens; B. subtilis, S. aureus, E. coli, S. typhimurium and has shown broad spectrum activity which has been reported in the Table 3 . The other extracts displayed significantly smaller inhibition zones when compared to $P$. neglecta. Crude extract from methanol and ethyl acetate have shown highest zone of inhibition $14.5 \mathrm{~mm}$ against $S$. aureus and $15 \mathrm{~mm}$ against E. coli, respectively (Figs. 1,2). The bioactivity profiles of fungal crude extracts suggested compounds with strong and specific bioactivity. Specific bioactivity, defined as high inhibition of growth of one type of target organism with little or no activity against others, is of particular interest in drug discovery: it suggests the presence of compounds that have specific modes of action as opposed to highly toxic compounds that are often of little use as medication (Kaczorowski et al. 2011). The genus Pestalotiopsis has received considerable attention in recent years, because of its role as a commonly isolated endophyte which has been shown to produce a wide range of chemically novel diverse metabolites (Maharachchikumbura et al. 2011). For this reason, this fungus was chosen for further study.

Antimicrobial activity present from fungal crude extract has been conducted and proved by many studies (Garcia et al. 2012; Idris et al. 2013). Some extracts were effective against all the bacterial pathogens included in the study. These results might be attributed either to the antimicrobial potency of the extract or to the high concentration of unidentified active principle in the extracts. Other endophytic fungal extracts which showed low anti-microbial activity in the bioassay may have active compounds but probably in smaller amounts and/or the screened crude extracts could yield more potent compounds once they had undergone some purification (Idris et al. 2013). However, low activity of fungal crude extract does not indicate that this fungus does not have any activity.

Endophytic fungi isolated from spike of coniferous plant were tested with respect to their production of
Fig. 1 Antibacterial activity of Pestalotiopsis neglecta methanol extract against a Bacillus subtilis,

b Escherichia coli, c Salmonella typhimurium and

d Staphylococcus aureus
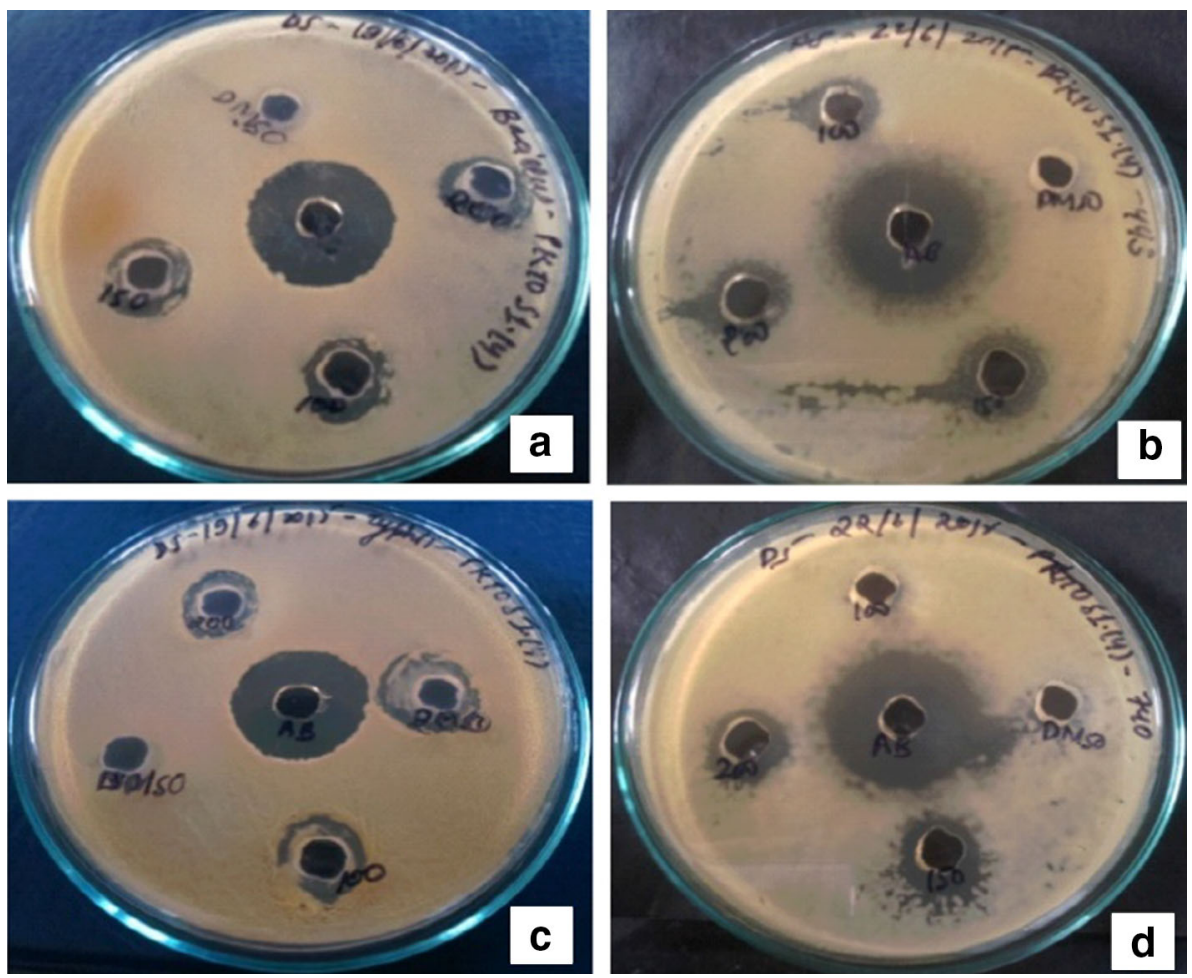
Fig. 2 Antibacterial activity of Pestalotiopsis neglecta ethyl acetate extract against a Bacillus subtilis,

b Escherichia coli, c Salmonella typhimurium and

d Staphylococcus aureus
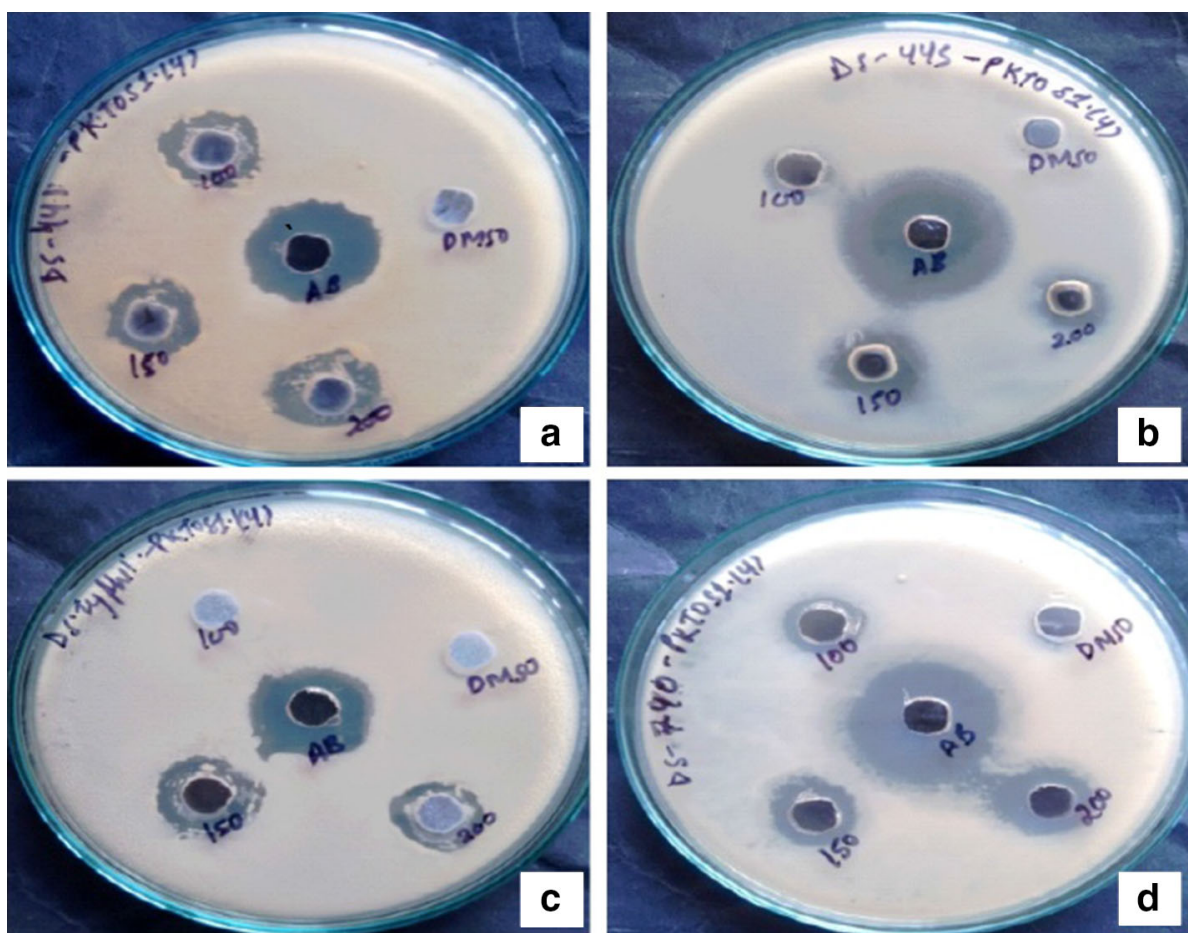

antimicrobial compounds against human pathogenic microorganisms such as E. coli, S. aureus, S. typhimurium, Candida albicans, Rhizoctonia solani, Cladosporium herbarum using an agar diffusion assay. The fungal crude extract did not show any activity against fungal pathogen such as $R$. solani, $C$. herbarum. The structural differences presented in the cellular walls of different types of bacteria and fungi (Tortora et al. 2005) are likely to affect the performance of the crude extract. This may explain why the performance of the extract was poorer in the yeast and in the Gram-negative bacterium.

Bioactive compounds isolated from endophytic fungi also displayed antimicrobial activity. Taxol, a natural product isolated from $C$. cladosporioides, showed a potent minimum inhibitory concentration against several pathogenic Gram-positive bacteria (Zhang et al. 2009), suggesting that this compound could be present in the crude extract of the fermentation of $P$. neglecta, which requires confirmation. Pestalotiopsis sp. from leaves of Syzygium cumini revealed considerable antimicrobial activity against human pathogenic bacteria viz Staphylococcus aureus and Salmonella typhi alone and in combination with commercially available antibiotics (Rahman et al. 2011). Pestalotiopsis microspora was isolated from Taxus wallichiana was screened using preliminary monoclonal antibody test indicate it may produce taxol (Strobel 2003). It appeared that fungi more commonly produced taxol than higher plants, and the distribution of those fungi making taxol is worldwide and not confined to endophytes of yews. Thus, it may be that taxol had its origins in certain fungi and ultimately, if there is lateral gene transfer, it may have been in the direction of the microbe to the higher plant. Similarly, Subbulakshmi et al. (2012) have reported that methanol extract of Pestalotiopsis sp. isolated from the Biota orientalis exhibited significant antibacterial and antifungal activity. Gomes Figueiredo et al. (2007) reported antibacterial activity of Pestalotiopsis sp. isolated from medicinal plant Maytenus ilicifolia, a medicinal plant from Brazil. The results revealed that the metabolites of $P$. neglecta are the potential source for the development of new antimicrobial compounds.

\section{Minimum inhibitory concentration of fungal crude extract}

Crude extracts showing potent antibacterial activity was further examined for their MIC by a tube dilution technique against $S$. aureus, B. subtilis, S. typhimurium and E. coli (Table 4). Isolates of both the extracts have shown MIC ranged from 25 to $6.25 \mathrm{mg} / \mathrm{mL}$ for $S$. typhimurium, $S$. aureus, $E$. coli and B. subtilis. The methanol extract of fungal culture showed MIC of $6.25 \mathrm{mg} / \mathrm{mL}$ for $S$. aureus whereas ethyl acetate extract showed MIC of $6.25 \mathrm{mg} / \mathrm{mL}$ for $S$. typhimurium which showed its efficacy as a potent antimicrobial. The MIC of ethyl acetate extract of Nigrospora sp. was evaluated by tube broth dilution method was recorded as $2.5 \mathrm{mg} /$ $\mathrm{mL}$ against E. coli, S. aureus, C. albicans and Geotrichum sp. (Pawle and Singh 2014). The methanol and ethyl acetate extracts of endophytic fungi isolated from 
Table 4 Minimum Inhibitory Concentration of the crude methanol and ethyl acetate extract of fungal isolate

\begin{tabular}{lll}
\hline \multicolumn{2}{l}{ Minimum inhibitory concentration $(\mathrm{mg} / \mathrm{mL})$} \\
\hline Bacterial pathogens & Methanol extract & Ethyl acetate extract \\
\hline$S a$ & 6.25 & 12.5 \\
$E c$ & 12.5 & 25 \\
$S t$ & 6.25 & 6.25 \\
$B s$ & 25 & 12.5 \\
\hline
\end{tabular}

Bs, Bacillus subtilis; Sa, Staphylococcus aureus; Ec, Escherichia coli; St, Salmonella typhimurium

Indigofera suffruticosa have shown MIC value 1.56 and $0.39 \mathrm{mg} / \mathrm{mL}$ for $S$. aureus (Santos et al. 2015). Since our study was the primary screening for the antibacterial activity of these extracts, assaying minimum inhibitory concentration (MIC) of them are suggested in order to strengthen the findings of the current study. Moreover, attempts should be made, using analytical chemistry procedures, to isolate and identify the bioactive compounds responsible for the antibacterial activity reported here.

\section{Phytochemical screening of crude extract of endophytic fungi}

Chemical analysis was carried out of fungal crude extracts to determine the presence of chemical components as a prospective source for medicinal and industrial use (Bisht et al. 2016) (Table 5). Their presence is an indicator that they can be exploited as precursors in the development and advancement of synthetic drugs. The active metabolites contain chemical groups such as phenols, flavonoids, terpenoids, alkaloids, tannins, carbohydrates and saponins. Only two phytocomponents were present in ethyl acetate extract, i.e., saponins, flavonoids, phenols and alkaloids whereas methanolic crude extract exhibited all phytocomponents except saponin. The phytochemical analyses of the ethyl acetate crude extracts of Penicillium frequentans have shown the presence of almost all the phytochemicals

Table 5 Phytochemical screening of the methanol and ethyl acetate extracts of fungal isolate

\begin{tabular}{lll}
\hline Phytocomponents & Methanol extract & Ethyl acetate extract \\
\hline Saponins & - & + \\
Phenols & + & + \\
Tannins & + & - \\
Terpenoids & + & - \\
Flavonoids & + & + \\
Alkaloids & + & + \\
Carbohydrates & + & + \\
\hline
\end{tabular}

(Bhardwaj et al. 2015). The phytochemical screening of ethyl acetate extract of Penicillium sp. isolated from Centella asiatica have shown the presence of alkaloids, phenols, flavonoids, tannin and glycosides (Devi et al. 2012). The ability of an endophyte to produce some metabolites but not others has been described by (Selim et al. 2012) where different endophytes in a plant may produce different secondary metabolites hence play different functions in the plant and that the total number of metabolites in a plant extract maybe a contribution of all the endophytes that live on the plant. The production and quality of bioactive compounds from endophytic fungi depend on natural conditions of the association and the nature of the synthetic medium used (Strobel and Daisy 2003). Strategies can be developed to use these fungi for exploitation of bioactive compounds.

\section{MTT cytotoxicity assay of the fungal crude extracts}

The cytotoxic activity of methanol and ethyl acetate extracts of endophytic fungi was performed on HEK cell line to check the bioactivity of them (Figs. 3, 4). The MTT assay was carried out at different concentrations of the extracts in the cell line. The OD was measured at $560 \mathrm{~nm}$ with reference OD at $630 \mathrm{~nm}$ at 24 and $48 \mathrm{~h}$. In this culture, the $\%$ viability was enhanced at $48 \mathrm{~h}$ and reduced at $24 \mathrm{~h}$ of both the crude extracts at $10 \mu \mathrm{g} / \mathrm{mL}$ concentration. Thus, current study showed that the effect of its secondary metabolites on the cell viability of HEK cell lines. The cells treated with the fungal extracts of concentration ranging between 125 and $500 \mu \mathrm{g} / \mathrm{mL}$ showed a significant decrease in the cell viability (Lakshmi and Selvi 2013). The extracts showed a high significant activity against the cancer cells. Thus, the isolate showed the potential to be used as anticancer drugs and needed to be further investigated.

Endophytic fungi extracts isolated from Garcinia plant were screened and $33 \%$ of the screened extracts, showed

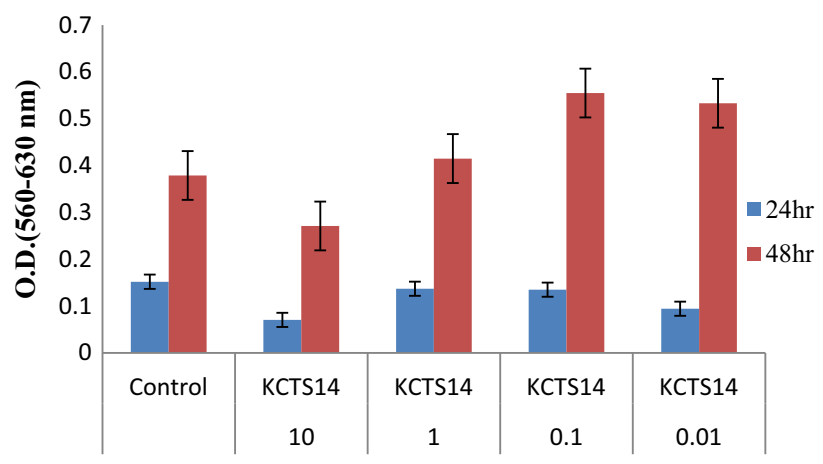

Fig. 3 MTT cytotoxicity assay of the methanolic crude extracts of Pestalotiopsis neglecta (metabolic viability: Effect of KCTS14 methanol extract in HEK) 


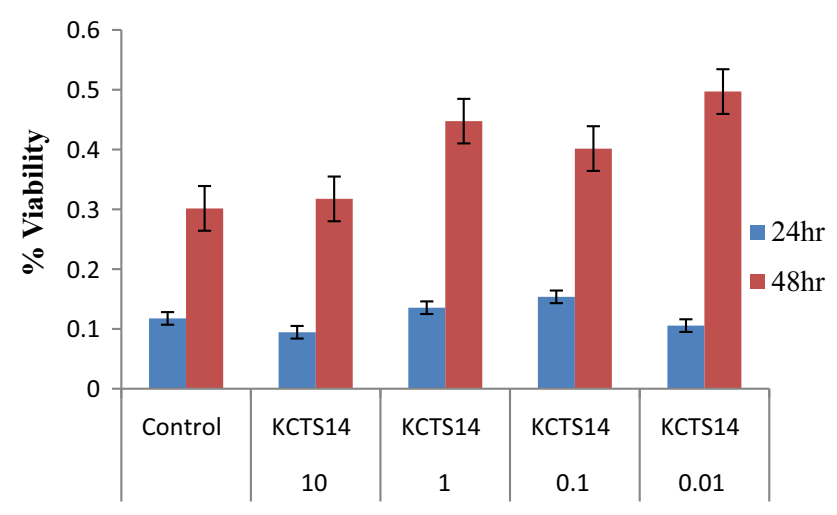

Fig. 4 MTT cytotoxicity assay of the ethyl acetate extract crude extracts of Pestalotiopsis neglecta (Metabolic viability: effect of KCTS14) ethyl acetate extract in HEK)

cytotoxic activity at concentration $10 \mu \mathrm{g} / \mathrm{mL}$ for Vero cell line (Phongpaichit et al. 2006). Endophytic fungi isolated from Viguiera arenaria and Tithonia diversifolia was found to be cytotoxic for JURKAT cell line at concentration of $20 \mu \mathrm{g} / \mathrm{mL}$ (Guimaraes et al. 2008). Endophytic fungi isolated from Bacopa monnieri (L.) Pennell (Scrophulariaceae) has shown cytotoxic activity $>20 \mu \mathrm{g} / \mathrm{mL}$ for HCT-116 cell line (Katoch et al. 2014).

Endophytic fungus BS1 was isolated from Piper crocatum Ruiz and Pav (P. crocatum) and have shown cytotoxic activity for WiDr and T47D cell lines with 120.38 and $37.43 \mu \mathrm{g} / \mathrm{mL}$, respectively (Astuti and Nababan 2014). The fungal taxol extracted also showed a strong cytotoxic activity in the in vitro culture of human cancer cells tested in an apoptotic assay (Kumaran et al. 2008b).

\section{Thin layer chromatographic analysis and partial purification of bioactive compound}

The fungal crude extract prepared from the cell-free culture filtrates showed strong antibacterial and cytotoxic activity. The crude extract was subjected to TLC analysis for the separation of the bioactive compounds. Two fractions designated as first and second were observed when developed in dichloromethane: methanol (90:10) on silica gel TLC plates and sprayed with ceric sulfate. These were eluted out and checked for antibacterial activity; only second fraction having $\mathrm{Rf}=0.79$ exhibited the antibacterial activity. The spot showed purplish color when sprayed with ceric sulfate. Preparative TLC was carried out to obtain sufficient crude material for further analysis.

\section{Detection of bioactive compounds by GC-MS analysis}

The crude extract was partially purified by TLC analysis. The partially purified crude was subjected to GC-MS analysis which showed Retention time, area \%, molecular formula and molecular weights of the several compounds were identified and tabulated (Table 6). The gas chromatography results of fungal crude extract reveal that major active compounds of Pestalotiopsis sp. BAB-5510 are nonadecane (19.74\%), 1,2,3-propanetriol, 1-acetate (17.21\%), bis(2-ethylhexyl) phthalate $(14.41 \%)$ and $4 \mathrm{H}$ pyran-4-one, 2,3-dihydro-3,5-dihydroxy-6-methyl- (11.62) and 5-hydroxymethylfurfural (10.09) were the compounds showed highest area \% (Fig. 5) and have antimicrobial activities and cytotoxic activity. GC-MS analysis of metabolites from endophytic fungus Colletotrichum gloeosporioides isolated from Phlogacanthus thyrsiflorus Nees have shown the presence of phenol,2,4-bis(1,1-dimethylethyl), 1-hexadecene, 1-hexadecanol, hexadecanoic acid, octadecanoic acid methyl ester and 1-nonadecane. The compounds produced by endophytic fungi could be an alternative source for human welfare (Devi and Singh 2013). GC-MS analysis of Polycarpaea corymbosalams also showed similar compounds such as 5-hydroxymethylfurfural (26.68) along with 2-chlorophenyl isothiocyanate (11.10) in root and n-Hexadecanoic acid (14.28) and Oleic Acid (12.94) in aerial parts were determined to be the compounds of high peak areas which mainly indulge in the anti-inflammatory properties (Sindhu and Manorama 2013). Pharmaceutical microbiology screening programs have shown that secondary metabolites can be isolated which bind to active sites of enzymes and receptors. Phthalates are reported to have antimicrobial and other pharmacological activities. Bis(ethyl hexyl) phthalate reported from Streptomyces bangladeshiensis showed antimicrobial activity against Gram positive bacteria and some pathogenic fungi (Al-Bari et al. 2006). First occurrence of bis-(-ethylhexyl) phthalate from $S$. bangladeshiensis and naturally occurring dioctyl phthalate showed antimicrobial activity against Gram-positive bacteria were reported very recently. The presence of various bioactive compounds (identified as phthalate esters, phthalate, alkanes, esters, alcohols, sugar, sesquiterpenoids) justifies the use of the whole plant for various ailments by traditional practitioners (Ramalakshmi and Muthuchelian 2011).

1, 2-Benzenedicarboxylic acid bis(2-ethylhexyl) phthalate has been isolated from a marine algae, Sargassum weightii, and apart from its plasticizing ability it was also found to have antibacterial effect on a number of bacteria (Sastry and Rao 1995; Sivakumar 2014). These obtained antibacterial compounds should then be evaluated against wider range of bacterial strains as well as in vivo, and tested for their safety and efficacy as therapeutic principles against infectious disease.

These fungi could, thus, be used to produce biofuels from cellulosics without the need for hydrolytic pretreatments. Gas chromatography-mass spectrometry-solid- 
Fig. 5 GC-MS chromatogram of KCTS14 methanol extract

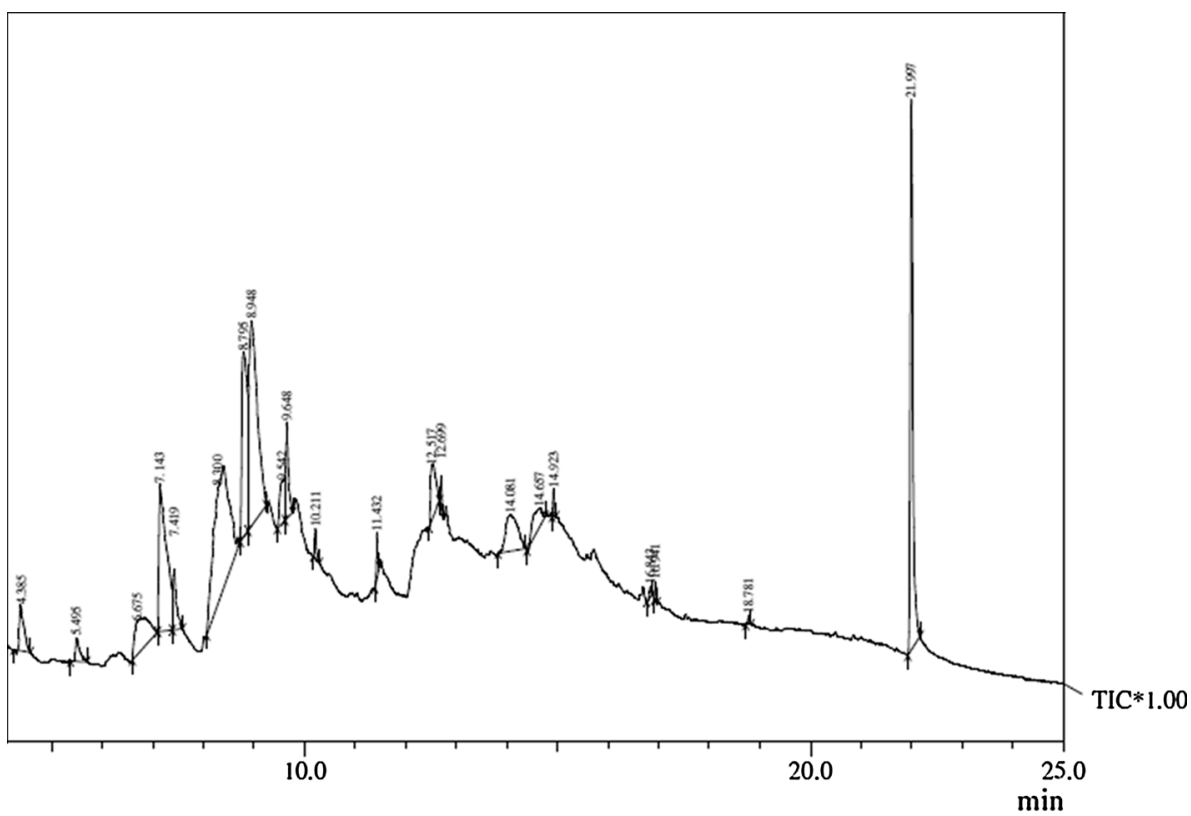

phase micro-extraction (GC-S-SPME) of head space gases from an endophytic fungi, Gliocladium demonstrated the production of $\mathrm{C}(6)-\mathrm{C}(19)$ hydrocarbons including hexane, benzene, heptane, 3,4-dimethyl hexane, 1-octene, $\mathrm{m}$ xylene, 3-methyl nonane, dodecane, tridecane, hexadecane along with nonadecane directly from the cellulosic biomass. These fungi could potentially be developed into costeffective biocatalysts for production of biofuels (Ahamed and Ahring 2011).

From the above findings it may be concluded that $P$. neglecta produces secondary metabolites in its culture filtrate. Thus, fungal crude extract revealed that it has the capacity to produce secondary metabolites having antimicrobial activity and cytotoxic activity. Report from this study supports the growing evidence that bioactive compounds produced by fungal endophytes may not only be involved in the host-endophyte relationship, but may also ultimately have applicability in other industries also. Endophytic fungus can be exploited for the bioactive compound. Endophytes are present in almost all plant species and have been recognized as a potential source of novel medicinal compounds. From this work, we can conclude that the endophytic fungi have wide variety of bioactive compounds. However, further research is necessary to explore the secondary metabolites of $P$. neglecta which have different biological activities.

\section{Phenotypic and genotypic identification of endophytic fungi}

On PDA medium, the isolated fungal culture has appeared olive green in color with threadlike mycelia with wavy margins and which change in white color on surface after a week (Fig. 6a). The slide cultures prepared from this fungus showed septate hyphae with pigmented crystals along them (Fig. 6b). In addition to the morphological characterization, genotypic methods were carried out to confirm the identification of most promising endophytic fungal strain KCTS14 isolated from the $C$. torulosa D.Don. Genotypic identification techniques were used to determine the identity of the fungus to generic level. On the basis of its $18 \mathrm{~S}$ ribosomal RNA gene, partial sequence; internal transcribed spacer $1,5.8 \mathrm{~S}$ ribosomal RNA gene, and internal transcribed spacer 2, complete sequence and $28 \mathrm{~S}$ ribosomal RNA gene, partial sequence, it can be concluded that the fungus KCTS14 belongs to the genus P. neglecta. The fungal sequence was submitted in National Center for Biotechnology Information with accession number KT355732 with the name P. neglecta BAB 5447. The percentage of similarity between the fungus and database suggests it to be a novel strain. Molecular techniques have been successfully used for identifying endophytic fungi in recent studies (Devi et al. 2012). The morphological characters having phylogenetic significance have been demonstrated and reported by Jeewon et al. (2003) and Wei et al. (2005). It was proposed that when a new Pestalotiopsis species is described, morphological characters should be taken into account rather than host association and molecular phylogenetic information is also necessary to prove that the taxon is unique from other known species (Jeewon et al. 2004; Wei 2004).

Endophytic fungi have a worldwide distribution from tropical forests to arctic environments and have been reported from various plants, including conifers, monocots, 
Table 6 Phytocomponents identified in KCTS14 methanol extract

\begin{tabular}{|c|c|c|c|c|c|c|}
\hline $\begin{array}{l}\text { S. } \\
\text { no. }\end{array}$ & RT & Name of compound & $\begin{array}{l}\text { Molecular } \\
\text { formula }\end{array}$ & MW & Area $\%$ & Activity \\
\hline 1 & 4.385 & 2,4-Dihydroxy-2,5-dimethyl-3(2H)-furan-3-one & $\mathrm{C}_{6} \mathrm{H}_{8} \mathrm{O}_{4}$ & 144 & 2.02 & Antimicrobial \\
\hline 2 & 5.495 & Pentanoic acid, 4-oxo- & $\mathrm{C}_{5} \mathrm{H}_{8} \mathrm{O}_{3}$ & 116 & 0.96 & Antibacterial \\
\hline 3 & 6.675 & Melamine & $\mathrm{C}_{3} \mathrm{H}_{6} \mathrm{~N}_{6}$ & 126 & 4.66 & - \\
\hline 4 & 7.143 & $\begin{array}{l}\text { 4H-Pyran-4-one, 2,3-dihydro-3,5-dihydroxy-6- } \\
\text { methyl- }\end{array}$ & $\mathrm{C}_{6} \mathrm{H}_{12} \mathrm{O}_{2}$ & 116 & 11.62 & $\begin{array}{l}\text { Antimicrobial, anti-inflammatory, } \\
\text { antiproliferative }\end{array}$ \\
\hline 5 & 7.419 & Dodecane & $\mathrm{C}_{12} \mathrm{H}_{26}$ & 170 & 2.12 & Antibacterial, biofuel production \\
\hline 6 & 8.300 & Nonadecane & $\mathrm{C}_{3} \mathrm{H}_{6} \mathrm{O}_{3}$ & 90 & 19.74 & Cytotoxic effect, Antibacterial \\
\hline 7 & 8.795 & 5-Hydroxymethylfurfural & $\mathrm{C}_{6} \mathrm{H}_{6} \mathrm{O}_{3}$ & 126 & 10.09 & Antimicrobial \\
\hline 8 & 8.948 & 1,2,3-Propanetriol, 1-acetate & $\mathrm{C}_{5} \mathrm{H}_{10} \mathrm{O}_{4}$ & 134 & 17.21 & Antibacterial \\
\hline 9 & 9.542 & Heptose & $\mathrm{C}_{7} \mathrm{H}_{14} \mathrm{O}_{7}$ & 210 & 2.36 & - \\
\hline 10 & 9.648 & Triacetin & $\mathrm{C}_{9} \mathrm{H}_{14} \mathrm{O}_{6}$ & 218 & 2.72 & Antibacterial \\
\hline 11 & 10.211 & 2,3-Dihydroxypropanal & $\mathrm{C}_{14} \mathrm{H}_{30}$ & 198 & 0.51 & Antimicrobial \\
\hline 12 & 11.432 & 1-Cycloheptene & $\mathrm{C}_{15} \mathrm{H}_{24}$ & 204 & 0.73 & - \\
\hline 13 & 12.517 & D-Allose & $\mathrm{C}_{6} \mathrm{H}_{12} \mathrm{O}_{6}$ & 180 & 2.92 & Antibacterial \\
\hline 14 & 12.699 & Pentadecane & $\mathrm{C}_{15} \mathrm{H}_{32}$ & 212 & 0.32 & Antibacterial \\
\hline 15 & 14.081 & 1,5-Anhydrohexitol & $\mathrm{C}_{6} \mathrm{H}_{12} \mathrm{O}_{5}$ & 164 & 2.11 & - \\
\hline 16 & 14.657 & 3-Deoxy-D-mannoic lactone & $\mathrm{C}_{6} \mathrm{H}_{10} \mathrm{O}_{5}$ & 162 & 0.39 & Antimicrobial \\
\hline 17 & 14.923 & Tetradecane & $\mathrm{C}_{19} \mathrm{H}_{40}$ & 268 & 0.20 & Antimicrobial \\
\hline 18 & 16.843 & 1,2-Benzenedicarboxylic acid & $\mathrm{C}_{22} \mathrm{H}_{34} \mathrm{O}_{4}$ & 362 & 0.24 & Antibacterial \\
\hline 19 & 16.941 & Heneicosane & $\mathrm{C}_{21} \mathrm{H}_{44}$ & 296 & 0.16 & Antibacterial \\
\hline 20 & 21.997 & Bis(2-ethylhexyl) phthalate & $\mathrm{C}_{24} \mathrm{H}_{38} \mathrm{O}_{4}$ & 390 & 14.41 & Antibacterial \\
\hline
\end{tabular}

Fig. 6 a Colony morphology on PDA of KCTS14 b Shape of conidia by staining techniques
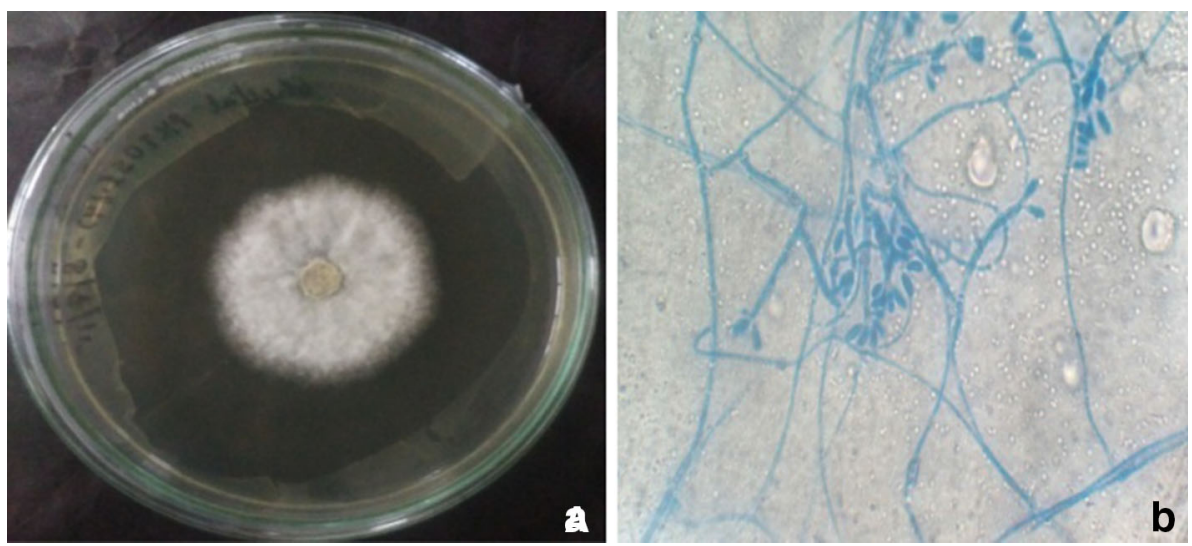

dicots, ferns and lycopsids (Brunner and Petrini 1992). However, this is the first report of an endophytic $P$. neglecta BAB 5447 from the Garhwal, Himalayan gymnosperm. In the current investigation, morphotypic character of fungal colony was observed in PDA plates and conidia structure by Lacto-phenol cotton blue slide staining methods. LPCB staining techniques results showed that spore release the apophyses and columella often collapse to form an umbrella-like structures which made this fungus very unusual and also difficult to identify to the species level. Therefore, genotypic methods have been used to find out the relationships of species within the genus (Brunner and Petrini 1992; Yoo and Eom 2012). More precise taxonomic identification of this fungus may require more prudent molecular techniques, expansion of fungal genomic database and further studies using several cultures of the same fungus.

\section{Conclusion}

Endophytic fungi reside in the interior of healthy plants without causing them any damage. These fungi are of biotechnological interest; they may be used in the 
biological control of pests and plant diseases, and in the pharmaceutical industry. Compounds of medicinal value derived from various endophytic fungi have made immense contribution towards the betterment of human health and act as a source of inspiration for novel drug compounds. In this work, both the crude extracts of fungal isolates showed antibacterial activity against bacterial human pathogens such as S. typhimurium, E. coli, S. aureus and B. subtilis. The experiment on cytotoxic activity of endophytic fungi was performed on HEK cell line which enhanced the metabolic activity of the cells in $48 \mathrm{~h}$. Both the endophytic fungal extracts also exhibited significant presence of different phytochemicals. The presence of bioactive compounds was further identified using GC-MS and shown the presence of different antimicrobial compounds. Current study concluded that fungus $P$. neglecta BAB-5510 has an ability to produce various secondary metabolites which may be used in the area of pharmacology and also as a prospective source of valuable drugs. However, isolation of individual secondary metabolite constituents and subjecting it to biological activity will definitely give fruitful results. However, further studies will need to be undertaken to ascertain fully its bioactivity, toxicity profile effect on the ecosystem and agricultural products. Insights from such research would provide alternative methods of natural product drug discovery which could be reliable, economical, and environmentally safe. The potential of these fungi is of great interest and warrants further investigation.

Acknowledgments We gratefully acknowledge TEQIP-II and G. B. Pant Engineering College, Pauri, Garhwal for providing financial support for conducting this research.

\section{Compliance with ethical standards}

Conflict of interest We certify that there is no conflict of interest with any financial organization regarding the material discussed in the manuscript.

Open Access This article is distributed under the terms of the Creative Commons Attribution 4.0 International License (http:// creativecommons.org/licenses/by/4.0/), which permits unrestricted use, distribution, and reproduction in any medium, provided you give appropriate credit to the original author(s) and the source, provide a link to the Creative Commons license, and indicate if changes were made.

\section{References}

Ahamed A, Ahring BK (2011) Production of hydrocarbon compounds by endophytic fungi Gliocladium species grown on cellulose. Bioresour Technol 102(20):9718-9722

Al-Bari MAA, Sayeed MA, Rahman MS, Mossadik MA (2006) Characterization and antimicrobial activities of a phthalic acid derivative produced by Streptomyces bangladeshiensis, a novel species collected in Bangladesh. Res J Med Med Sci 1(2):77-81
Almeida ER, Chaves TM, Luna RLA, Silva AR, Aragao-Neto AC, Silva LLS et al (2013) Anticonvulsant effect of Indigofera suffruticosa Mill: indication of involvement of the GABAergic system. Afr J Pharm Pharmacol 7:622-628

Arnold AE, Henk DA, Eells RL, Lutzoni F, Vilgalys R (2007) Diversity and phylogenetic affinities of foliar fungal endophytes in loblolly pine inferred by culturing and environmental PCR. Mycologia 99(2):185-206

Astuti P, Nababan OA (2014) Antimicrobial and cytotoxic activities of endophytic fungi isolated from Piper crocatum Ruiz \& Pav. Asian Pac J Trop Biomed 4(Suppl 2):S592-S596

Bagyalakshmi TA, Ramesh V, Arivudainambi USE, Rajendran A (2012) A novel endophytic fungus Pestalotiopsis sp. Inhibiting Pinus canariensis with antibacterial and antifungal potential. Int J Adv Life Sci 1:1-7

Bandra WMM, Seneviratne G, Kulasooroya SA (2001) Infection among endophytic bacteria and fungi: effects and potential. J Biosci 3(1):645-650

Bezerra dos Santos AT, Araujo TFDS, Da Silva LCN, Silva CBD, Oliveira AFMD, Araujo JM et al (2015) Organic extracts from Indigofera suffruticosa leaves have antimicrobial and synergic actions with Erythromycin against Staphylococcus aureus. Front Microbiol 6:13

Bhardwaj A, Sharma D, Agrawal PK (2014) Isolation and characterization of endophytic fungi from spikes of Pinus roxburghii growing in Himalayan region. World J Pharm Res 3(9):568-579

Bhardwaj A, Sharma D, Jodan N, Agrawal PK (2015) Antimicrobial and phytochemical screening of endophytic fungi isolated from spikes of Pinus roxburghii. Arch Clin Microbiol 6(3):1-9

Bisht R, Sharma D, Agrawal PK (2016) Antagonistic and antibacterial activity of endophytic fungi isolated from needle of Cupressus torulosa D.Don. Asian J Pharm Clin Res 9(3):282-288

Brunner F, Petrini O (1992) Taxonomy of some Xylaria species and xylariaceous endophytes by isozyme electrophoresis. Mycol Res 96:723-733

Carli CBA, Quilles MB, Maia DC, Lopes FC, Santos R, Pavan FR et al (2010) Antimycobacterial activity of Indigofera suffruticosa with activation potential of the innate immune system. Pharm Biol 48:878-882

Carroll MC (2004) The complement system in regulation of adaptive immunity. Nat Immunol 5(10):981-986

Chen TY, Sun HL, Yao HT, Lii CK, Chen HW, Chen PY et al (2013) Suppressive effects of Indigofera suffruticosa Mill extracts on lipopolysaccharide-induced inflammatory responses in murine RAW 264.7 macrophages. Food Chem Toxicol 55:257-264

Clay K (1989) Clavicipitaceous endophytes of grasses: their potential as biocontrol agents. Mycol Res 92:1-12

Dar RA, Rather SA, Mushtaq S, Qazi PH (2015) Purification and characterization of endophytic fungal strains from four different high value medicinal plants of Kashmir valley. Int J Phytopharm Res 5(1):8-11

Deshmukh SK, Mishra PD, Kulkarni-Almeida VSA, Sahoo MR, Periyasamy G, Goswami H (2009) Anti-inflammatory and anticancer activity of ergoflavin isolated from an endophytic fungus. Chem Biodivers 6:784-789

Devi NN, Prabaka JJ, Wahab F (2012) Phytochemical analysis and enzyme analysis of endophytic fungi from Centella asiatica. Asian Pac J Trop Biomed 2:1280-1284

Devi NN, Singh MS (2013) GC-MS Analysis of metabolites from endophytic fungus Colletotrichum gloeosporioides isolated from Phlogacanthus thyrsiflorus Nees. Int J Pharm Sci 23(2):392-395

Dreyfuss MM, Chapela IH (1994) Potential of fungi in the discovery of novel, low molecular weight pharmaceuticals. In: Gullo VP (ed) The discovery of natural products with therapeutic potential. Butter Worth-Heineemann, London, pp 49-80 
Fernandes MDRV, Silva TAC, Pfenning LH, Costa-Neto CMD, Heinrich TA et al (2009) Biological activities of the fermentation extract of the endophytic fungus Alternaria alternata isolated from Coffea arabica L. Braz J Pharm Sci 45(4):677-685

Firakova S, Sturdíkova M, Muckova M (2007) Bioactive secondary metabolites produced by microorganisms associated with plants. Biologia 62:251-257

Garcia A, Rhoden SA, Bernardi-Wenzel J, Orlandelli RC, Azevedo JL, Pamphile JA (2012) Antimicrobial activity of crude extracts of endophytic fungi isolated from medicinal plant Sapindus saponaria L. J Appl Pharm Sci 2(10):35-40

Gehlot P, Bohra NK, Purohit DK (2008) Endophytic mycoflora of inner bark of Prosopis cineraria-a key stone tree species of Indian desert. Am Eur J Bot 1:1-4

Gherbawy Y, Gashgari R (2014) Molecular characterization of endophytic fungi from Calotropis procera plants in Taif region (Saudi Arabia) and their antifungal activities. Plant Biosyst 148(6):1085-1092

Gomes Figueiredo J, Pimentel IC, Vicente VA, Pie MR, Kava Cordeiro V, Galli Terasawa L et al (2007) Bioprospecting highly diverse endophytic Pestalotiopsis sp. with antibacterial properties from Maytenus ilicifolia, a medicinal plant from Brazil. Can J Microbiol 53:1123-1132

Guanatilaka AAL (2006) Natural products from plant-associated microorganisms: distribution, structural diversity, bioactivity, and implications of their occurrence. J Nat Prod 69:509-526

Guimaraes DO, Borges WS, Kawano CY, Ribeiro PH, Goldman GH et al (2008) Biological activities from extracts of endophytic fungi isolated from Viguiera arenaria and Tithonia diversifolia. FEMS Immunol Med Microbiol 52:134-144

Hawksworth DL (1991) The fungal dimension of biodiversity: magnitude, significance, and conservation. Mycol Res 95 (6):641-655

Hawksworth DL (2001) The magnitude of fungal diversity: the 1.5 million species estimated revisted. Mycol Res 105:1422-1432

Huang JX, Zhang J, Zhang XR, Zhang K, Zhang X (2014) Mucor fragilis as a novel source of the key pharmaceutical agents podophyllotoxin and kaempferol. Pharm Biol 52:1237-1243

Idris A, Ietidal A, Idris M (2013) Antibacterial activity of endophytic fungi extracts from the medicinal plant Kigelia africana. Egypt Acad J Biol Sci 5(1):1-9

Jeewon R, Liew ECY, Simpson JA, Hodgkiss IJ, Hyde KD (2003) Phylogenetic significance of morphological characters in the taxonomy of Pestalotiopsis sp. Mol Phylogenet Evol 27:372-383

Jeewon R, Liew ECY, Hyde KD (2004) Phylogenetic evaluation of species nomenclature of Pestalotiopsis in relation to host association. Fungal Divers 17:39-55

Kaczorowski GJ, Garcia ML, Bode J, Hess SD, Patel UA (2011) The importance of being profiled: improving drug candidate safety and efficacy using ion channel profiling. Front Pharmacol 2(78): $1-11$

Kariyawasam GK, Mithrasena YJPK, Fernando THPS, Wijesundara RLC, Wijesundara WSS (2012) A new cost effective method for extracting genomic DNA from fungi. Colombo: Institute of Biochemistry, Molecular Biology and Biotechnology; Abstracts of papers, 5th annual sessions of Institute of Biochemistry, Molecular Biology and Biotechnology, Colombo, vol 5, pp 49

Katoch M, Singh G, Sharma S, Gupta N, Sangwan PL, Saxena AK (2014) Cytotoxic and antimicrobial activities of endophytic fungi isolated from Bacopa monnieri (L.) Pennell (Scrophulariaceae). BMC Complement Altern Med 14(52):1-8

Kaul S, Gupta S, Ahmed M, Dhar MK (2012) Endophytic fungi from medicinal plants: a treasure hunt for bioactive metabolites. Phytochem Rev 11:487-505

Kogel KH, Franken P, Huckelhoven R (2006) Endophyte or parasitewhat decides? Curr Opin Plant Biol 9:358-363
Kumaran RS, Muthumary J, Hur BK (2008a) Isolation and identification of taxol, an anticancer drug from Phyllosticta melochiae Yates, and endophytic fungus of Melochia corchorifolia L. Food Sci Biotechnol 17:1246-1253

Kumaran RS, Muthumary J, Hur BK (2008b) Production of taxol from Phyllosticta spinarum, an endophytic fungus of Cupressus sp. Eng Life Sci 8(4):438-446

Kusari S, Pandey SP, Spiteller M (2013) Untapped mutualistic paradigms linking host plant and endophytic fungal production of similar bioactive secondary metabolites. Phytochemistry 91:81-87

Lakshmi PJ, Selvi KV (2013) Anticancer potentials of secondary metabolites from endophytes of Barringtonia acutangula and its molecular characterization. Int $\mathrm{J}$ Curr Microbiol App Sci 2(2):44-45

Leite SP, Medeiros PL, Silva EC, Maia MBS, Lima VLM, Saul DE (2004) Embryo toxicity in vitro with extract of Indigofera suffruticosa leaves. Reprod Toxicol 18:701-705

Leite SP, Vieira JRC, Madeiros PL, Leite RMP, Lima VLM, Xavier HS et al (2006) Antimicrobial activity of Indigofera suffruticosa. Evid Based Complement Altern Med 3:261-265

Li Y, Song YC, Liu JY, Ma YM, Tan RX (2005) Anti-helicobacter pylori substances from endophytic fungal cultures. World $\mathrm{J}$ Microbiol Biotechnol 21:553-558

Li J, Zhao GZ, Chen HH, Wang HB, Qin S et al (2008) Antitumour and antimicrobial activities of endophytic streptomycetes from pharmaceutical plants in rainforest. Lett Appl Microbiol 47:574-580

Liang H, Xing Y, Chen J, Zhang D, Guo S, Wang C (2012) Antimicrobial activities of endophytic fungi isolated from Ophiopogon japonicus (Liliaceae). BMC Complement Altern Med 12(238): 1-6

Luiz-Ferreira A, Cola M, Barbastefano V, Farias-Silva E, Calvo TR, Almeida ABA et al (2011) Indigofera suffruticosa Mill as new source of healing agent: involvement of prostaglandin and mucus and heat shock proteins. J Ethnopharmacol 137:192-198

Maharachchikumbura SSN, Guo LD, Chukeatirote E, Bahkali AH, Hyde KD (2011) Pestalotiopsis morphology, phylogeny, biochemistry and diversity. Fungal Divers 50:167-187

Metwaly AM, Kadry HA, El-Hela AA, Mohammad AEI, Ma G, Cutler SJ (2014) Nigrosphaerin A a new isochromene derivative from the endophytic fungus Nigrospora sphaerica. Phytochem Lett $7: 1-5$

Molina G, Pimentel MR, Bertucci TCP, Pastore GM (2012) Application of fungal endophytes in biotechnological processes. Chem Eng Trans 27:289-294

Newman DJ, Cragg GM, Snader KM (2003) Natural products as sources of new drugs over the period 1981-2002. J Nat Prod 66:1022-1037

Pawle G, Singh SK (2014) Antimicrobial, antioxidant activity and phytochemical analysis of an endophytic species of Nigrospora isolated from living fossil Ginkgo biloba. Curr Res Environ Appl Mycol 4(1):1-9

Perottoab S, Angelinic P, Bianciottob V, Bonfanteab P, Girlandaab M, Kulld T et al (2013) Interactions of fungi with other organisms. Plant Biosyst 147:208-218

Petersen PJ, Wang TZ, Dushin RG, Bradford PA (2004) Comparative in vitro activities of AC98-6446, a novel semisynthetic glycopeptide derivate of the natural product mannopeptimycin alpha and other antimicrobial agents against gram-positive clinical isolates. Antimicrob Agents Chemother 48:739-746

Petrini O (1986) Taxonomy of endophytic fungi of aerial plant tissues. In: Fokkema NJ, van den Huevel J (eds) Microbiology of the phyllosphere. Cambridge University Press, Cambridge, pp $175-187$ 
Petrini O, Stone J, Carroll EE (1982) Endophytic fungi in evergreen shrubs in western Oregon-a preliminary study. Can J Bot 60:789-796

Phongpaichit S, Rungjindamai N, Rukachaisirikul V, Sakayaroj J (2006) Antimicrobial activity in cultures of endophytic fungi isolated from Garcinia sp. FEMS Immunol Med Microbiol 48:367-372

Porras-Alfaro A, Bayman P (2011) Hidden fungi, emergent properties: endophytes and microbiomes. Annu Rev Phytopathol 49:291-315

Rahman F, Deshmukh S, Ingle A, Gade A, Rai M (2011) Novel antimicrobial agent synthesized from an endophytic fungus Pestalotiopsis sp. isolated from leaves of Syzygium cumini. Nano Biomed Eng 3(3):174-178

Ramalakshmi S, Muthuchelian K (2011) Analysis of bioactive constituents from the leaves of Mallotus tetracoccus (roxb.) Kurz, by gas chromatography-mass spectrometry. Int J Pharmaceutic Sci Res 2(6):1449-1454

Sadananda TS, Govindappa M, Vinay Dutt G, Bhat B, Baishya P, Chandrappa CP (2014) Isolation and characterization of antiviral and ribosome inactivating protein from the endophytic fungi Alternaria sp. from Viscum album using MADLI-TOF-MS and their antibacterial activity. Drug Invention Today 6(2):105-112

Santos IP, Silva NL, Silva MV, Araujo JM, Cavalcant MSI, Lima VM (2015) Antibacterial activity of endophytic fungi from leaves of Indigofera suffruticosa Miller (Fabaceae). Front Microbiol 6(350): $1-7$

Sastry VMVS, Rao GRK (1995) Dioctyl phthalate and antibacterial compound from the marine brown alga Sargassum wightii. J Appl Physiol 7:185-186

Schulz B, Boyle C, Draeger S, Rommert AK, Krohn K (2002) Endophytic fungi: a source of novel biologically active secondary metabolites. Mycol Res 106:996-1004

Selim SA, El-Alfy S, Al-Ruwaili M, Abdo A, Al-Jaouni S (2012) Susceptibility of imipenem-resistant Pseudomonas aeruginosa to flavonoid glycosides of date palm (Phoenix dactylifera L.) tamar growing in Al Madinah, Saudi Arabia. Afr J Biotechnol 11(2):416-422

Sindhu S, Manorama S (2013) GC-MS determination of bioactive components of Polycarpaea corymbosa lams (Caryophyllaceae). Hygeia J D Med 5(1):5-9

Sivakumar SR (2014) GC-MS analysis and antibacterial potential of white crystalline solid from red algae Portieriahornemannii against the plant pathogenic bacteria Xanthomnas axonopodis pv. citri (Hasse) Vauterin et al. andXanthomonas campestris pv. malvacearum (smith 1901) dye 1978b. Int J of Adv Res 2(3):174-183

Song XQ, Zhang X, Han QJ, Li XB, Li G (2013) Xanthone derivatives from Aspergillus sydowii, an endophytic fungus from the liverwort Scapania ciliata S. Lac and their immunosuppressive activities. Phytochem Lett 6:318-321

Strobel GA (2003) Endophytes as sources of bioactive products. Microbes Infect 5:535-544
Strobel G, Daisy B (2003) Bioprospecting for microbial endophytes and their natural products. Microbiol Mol Biol Rev 67:491-502

Subbulakshmi GK, Thalavaipandian A,V. Ramesh V, Bagyalakshmi, Rajendran A (2012) Bioactive endophyticfungal isolates of Biota orientalis (L) Endl., Pinus excelsa Wall. and Thuja occidentalis L. Int J Adv Life Sci 4:2277-7581

Tortora GJ, Funke BK, Case CL (2005) Microbiologia, 8th edn. Artmed, Porto Alegre, cap. 4, pp 83

Turbyville TJ, Wijeratne EM, Liu MX, Burns AM, Seliga CJ (2006) Search for Hsp90 inhibitors with potential anticancer activity: isolation and SAR studies of radicicol and monocillin I from two plant-associated fungi of the Sonoran desert. J Nat Prod 69:178-184

Verma A, Johri BN, Prakash A (2014) Antagonistic evaluation of bioactive metabolite from endophytic fungus, Aspergillus flavipes KF671231. J Mycol, 2014:5, Article ID 371218

Wariso BA, Ebong O (1996) Antimicrobial activity of Kalanchoe pinnaata (Ntiele. Lam) pers. Afr J Pharm Drug Res 12:65-68

Wei JG (2004) Diversity of endophytic Pestalotiopsis on Podocarpaceae, Theaceae and Taxaceae, and molecular phylogenetics of Pestalotiopsis [D]. Zhejiang University, Ph.D. Thesis, China (in Chinese)

Wei JG, Tong X, Liang-Dong G (2005) Endophytic Pestalotiopsis species from southern China. Mycosystema 24:481-493

White TJ, Bruns T, Lee S, Aylor JWT (1990) Amplification and direct sequencing of fungal ribosomal RNA genes for phylogenetics in PCR protocols: a guide to methods and applications. In: Innis MA, Gelfand DH , Sninsky JJ, White TJ (eds), Academic Press, New York, pp 315-322

Wise R (2008) The worldwide threat of antimicrobial resistance. Curr Sci 95:181-187

Yan XN, Sikora IR, Zheng JW (2011) Potential use of cucumber (Cucumis sativus L.) endophytic fungi as seed treatment agents against root-knot nematode Meloidogyne incognita. J Zhejiang Univ Sci B 12:219-225

Yoo JJ, Eom AH (2012) Molecular Identification of endophytic fungi isolated from needle leaves of conifers in Bohye on mountain, Korea. Mycobiology 40(4):231-235

Yuanab ZL, Chena YC, Mac XJ (2011) Symbiotic fungi in roots of Artemisia аппиа with special reference to endophytic colonizers. Plant Biosyst 145:495-502

Zhang P, Zhou PP, Yu LJ (2009) An endophytic taxol producing fungus from Taxus media, Cladosporium cladosporioides MD2. Curr Microbiol 59:227-232

Zhang HW, Ying C, Bai XL (2014) Advancement in endophytic microbes from medicinal plants. Int $\mathbf{J}$ Pharm Sci Res 5:1589-1600

Zhao J, Li C, Wang W, Zhao C, Luo M (2013) Hypocrea lixii, novel endophytic fungi producing anticancer agent cajanol, isolated from pigeon pea (Cajanus cajan [L.] Millsp.). J Appl Microbiol 115:102-113 